\title{
PENGARUH BUDAYA ORGANISASI DAN DISIPLIN KERJA TERHADAP KINERJA KARYAWAN PT. RUTAN PALEMBANG
}

\author{
Dra. Hj. Delimawati, M.Si \\ Dosen Fakultas Ekonomi Universitas Palembang
}

\begin{abstract}
ABSTRAK
Tujuan dari penelitian ini adalah untuk menjelaskan Pengaruh Budaya Organisasi dan Disiplin Kerja Terhadap Kinerja Karyawan Pada PT. Rutan Palembang. Jenis penelitian ini adalah kuantitatif. populasi dalam penelitian ini adalah karyawan PT Rutan Palembang. Pengambilan data menggunakan sampling jenuh yang didistribusikan kepada 32 responden. Teknik pengumpulan data dalam penelitian ini adalah kuesioner dan dokumentasi dengn analisis regresi linear berganda.

Pengujian hipotesis menggunakan analisis regresi linear berganda, melalui uji $\mathrm{T}$ dan uji $\mathrm{F}$, dengan maksud untuk mengetahui pengaruh variabel independen terhadap variabel dependent pada tingkat kepercayaan $95 \%(\mathrm{a}=0,05)$. Hasil penguji pada uji $\mathrm{T}$ pada variabel budaya organisasi berpengaruh positif terhadap kinerja, hal terlihat dari nilai $t_{\text {hitung }}(3,551)>$ $\mathrm{t}_{\text {tabel }}(2,045)$, signifikansi $(0,00)$ di bawah atau lebih kecil dari 0,05 , sedangkan pada variabel disiplin kerja berpengaruh positif terhadap kinerja, hal terlihat dari nilai $t_{\text {hitung }}(2,212)>t_{\text {tabel }}$ $(2,045)$ dan signifikansi $(0,00)$ di bawah atau lebih kecil dari 0,05 . Pada pengujian pada uji $F$ pada variabel budaya organisasi dan disiplin kerja berpengaruh positif terhadap kinerja, hal terlihat dari nilai $\mathrm{F}_{\text {hitung }}(6,300)>\mathrm{F}_{\text {tabel }}(3,328)$, dan signifikansi $(0,01)$ di bawah atau lebih kecil dari 0,05 .
\end{abstract}

\section{Kata Kunci : Budaya Organisasi, Displin Kerja \& Kinerja}

\section{PENDahuluan}

\subsection{Latar Belakang}

Sumber Daya Manusia merupakan salah satu modal dan merupakan peranan yang paling penting dalam mencapai tujuan perusahaan, sehingga sumber daya manusia (SDM) dituntut untuk terus menerus mampu mengembangkan diri secara proaktif. Usaha melakukan perbaikan bagi pertumbuhan dan perkembangan perusahaanya untuk menjadi perusahaan yang unggul dan sukses perusahaan harus mampu memahami dengan baik ilmu manajemen sumber daya manusia, lalu mengimplementasikanya ke dalam perusahaan. Manajemen sumber daya manusia adalah perencanaan, pengorganisasian, pengarahan, dan pengendalian dari pengadaan, pengembangan, kompensasi, pengintegrasian, pemeliharaan, dan pemberhentian karyawan, dengan maksud terwujudnya tujuan perusahaan, individu, karyawan dan masyarakat. Dalam usaha pencapaian tujuan tersebut, perusahaan akan mengamati seberapa jauh proses dan hasil pekerjaan yang sedang berjalan maupun yang telah dicapai saat ini (Malayu S.P.Hasibuan, 2016: 11).

Budaya organisasi adalah sistem makna bersama yang dianut oleh anggota-anggotanya yang membedakan organisasi itu dan juga organisasi lainnya. Budaya organisasi dalam suatu perusahaan atau organisasi sangat dibutuhkan, karena budaya organisasi merupakan perangkat system nilai-nilai (values), keyakinan-keyakinan (belief) atau 
norma-norma yang telah berlaku, disepakati dan diikuti oleh anggota suatu organisasi sebagai pedoman prilaku dan pemecahan masalah-masalah organisasi, sehingga terdapat peran yang sangat penting dalam budaya organisasi untuk menjaga perusahaan berjalan sesuai dengan yang diharapkan. Budaya organisasi yang kuat akan membuat perusahaan maju dan berkembang (Robbin, 2016:721).

Budaya organisasi yang kuat merupakan pembangkit semangat yang paling berpengaruh dalam menuntun perilaku karena dapat membantu para karyawan melakukan pekerjaanpekerjaannya dengan lebih baik, nilainilai budaya dapat diterjemahkan sebagai filosofi usaha, asumsi dasar, slogan atau moto perusahaan atau organisasi, tujuan umum organisasi dan prinsip-prinsip yang menjelaskan usaha. Nilai-nilai tersebut apabila dianut dan dilaksanakan secara bersama oleh pemimpin dan anggota organisasi dapat memperkuat budaya organisasi.

Kedisiplinan adalah kesadaran dan kesediaan seseorang mentaati semua peraturan perusahaan dan norma-norma sosial yang berlaku. Dengan disipliln yang tinggi akan dapat membantu meningkatkan kinerja.Untuk dapat menjadi perusahaan yang mempunyai daya saing pada ekonomi global yang semakin berkembang, maka perusahaan dituntut untutk dapat meningkatkan produktivitas kerja karyawan dan menciptakan kedisiplinan para karyawan demi mencapai tujuan perusahaan (Malayu S.P Hasibuan, 2016 ; 193).

Sehubungan dengan objek penelitian PT. Rutan Palembabg, peneliti melakukan pra survei dimana masih ada karyawan yang mempunyai budaya organisasi yang kurang baik. Hal terlihat keluar masuk karyawan (turnover) dan ketidakhadiran karyawan dalam bekerja. Berikut ini data keluar masuk karyawan (turnover) PT. Rutan Palembang dari tahun 2016-2020.

Tabel 1.1

PT. Rutan Palemabng

\begin{tabular}{|c|c|c|c|c|c|c|}
\hline \multirow[b]{2}{*}{ Tahun } & \multirow{2}{*}{$\begin{array}{c}\text { Jumlah } \\
\text { karyawan } \\
\text { Awal tahun }\end{array}$} & \multicolumn{2}{|c|}{$\begin{array}{c}\text { Jumlah } \\
\text { Karyawan }\end{array}$} & \multirow{2}{*}{$\begin{array}{c}\text { Jumlah } \\
\text { Karyawan } \\
\text { Akhir Tahun }\end{array}$} & \multirow{2}{*}{$\begin{array}{c}\text { Jumlah } \\
\text { rata-rata } \\
\text { karyawan }\end{array}$} & \multirow{2}{*}{$\begin{array}{l}\text { Tingkat } \\
\text { LTO }(\%)\end{array}$} \\
\hline & & Masuk & Keluar & & & \\
\hline 2016 & 26 & 10 & 2 & 34 & 30 & 6,67 \\
\hline 2017 & 34 & - & 2 & 32 & 33 & 6,06 \\
\hline 2018 & 32 & 5 & 1 & 36 & 34 & 2,94 \\
\hline 2019 & 36 & 10 & 4 & 42 & 39 & 10.26 \\
\hline 2020 & 42 & - & 10 & 32 & 37 & 27,03 \\
\hline
\end{tabular}

Sumber: PT. Rutan Tahun 2020

Dari tabel 1.1 diatas terlihat adanya jumlah karyawan masuk dan keluar. Pada tahun 2016 jumlah karyawan awal tahun 26 orang, karyawan masuk 10 orang jadi semuanya berjumlah 36 orang dan keluar 2 orang jadi $36-2=34$ orang karyawan pada akhir tahun dengan tingkat LTO 6,67. Pada tahun 2017 jumlah karyawan awal tahun 34 orang, karyawan masuk tidak ada 
sehingga berjumlah 34 orang dan yang keluar 2 orang jadi 34-2=34 orang dengan tingkat LTO yang menurun menjadi 6,06,5\%. Pada tahun 2018 jumlah karyawan awal tahun 32 orang, karyawan yang masuk 5 orang jadi semuanya berjumlah 37 orang dan yang keluar 1 orang jadi $37-1=36$ orang dengan tingkat LTO 2,94\%. Pada tahun 2019 jumlah karyawan awal tahun 36 orang, karyawan yang masuk 10 orang jadi semuanya berjumlah 46 orang dan yang keluar 4 orang jadi $46-4=42$ orang karyawan pada akhir tahun dengan tingkat LTO yang naik dibanding tahun sebelumnya yaitu sebesar 10,26\%.
2020 jumlah karyawan awal tahun 42 orang, karyawan yang masuk tidak ada dan yang keluar 10 orang jadi $42-10=$ 32 orang karyawan pada akhir tahun dengan tingkat LTO yang tinggi dari tahun sebelumnya yaitu sebesar 27,03\%. Keluar masuknya karyawan yang tinggi tersebut terjadi karena disebabkan oleh mereka merasa kurang puas dengan lingkungan kerja yang tidak nyaman, hubungan yang kurang haromonis, serta juga bisa disebabkan karena tidak sebandingnya kompensasi yang di terima, sehingga mereka berusaha mencari pekerjaan lain yang dianggap lebih sesuai.

Tabel 1.2

Perkembangan Jumlah Karyawan yang keluar Pada PT. Rutan Palembang

\begin{tabular}{|c|c|c|c|c|}
\hline Tahun & $\begin{array}{c}\text { Jumlah } \\
\text { karyawan } \\
\text { keluar }\end{array}$ & $\begin{array}{c}\text { Jumlah } \\
\text { karyawan } \\
\text { di PHK }\end{array}$ & $\begin{array}{c}\text { Jumlah } \\
\text { karyawan } \\
\text { mengundurkan }\end{array}$ & Jumlah \\
\hline 2016 & 2 & - & 2 & 2 \\
\hline 2017 & 2 & 1 & 1 & 2 \\
\hline 2018 & 1 & - & 1 & 1 \\
\hline 2019 & 4 & 2 & 2 & 4 \\
\hline 2020 & 10 & 10 & - & 10 \\
\hline
\end{tabular}

Sumber: PT. Rutan Tahun 2020

Dari tabel 2 terlihat tahun 2016 jumlah karyawan keluar sebanyak 2 orang dengan mengundurkan diri. Tahun 2017 jumlah karyawan keluar 2 orang, 1 orang PHK, 2 orang mengundurkan diri. Tahun 2018 karyawan keluar 1 orang mengundurkan diri. Tahun 2019 karyawan keluar 4 orang, 2 orang PHK dan 2 orang mengundurkan diri. Tahun 2020 karyawan keluar sebanyak 10 orang karena Pemutusan Hubungan Kerja (PHK) disebabkan karena adanya wabah pandemic virus Corona (Covid-19) yang melanda dunia termasuk Indonesia.
Hal ini diungkapkan oleh Ibu Emira Fadillah, SE. selaku HRD di PT. Rutan Palembang. "Adapun adanya karyawan yang di PHK pada tahun 2017 dan tahun 2019, dikarenakan pihak perusahaan ini mengutamakan kejujuran dalam kegiatan perusahaan, selain itu adanya ketidakpuasan perusahaan terhadap kinerja karyawan tersebut. Indisipliner pada karyawan dan beberapa tindak kejahatan yang dilakukan karyawan sehingga terjadi PHK. Sedangkan alasan adanya pengunduran diri secara garis besar adalah 
karyawan ingin mencari pengalaman baru ditempat yang baru. Tetapi ada beberapa alasan lain misalnya jumlah kompensasi yang diperoleh tidak cukup memadai, kurangnya kesempatan untuk berkembang di perusahaan, pekerjaan yang kurang menantang, kurangnya ketersediaan peralatan kerja yang kurang memadai sehingga menjadi salah satu faktor karyawan keluar, persaingan antar karyawan, lingkungan kerja yang tidak. Sedangkan pada tahun 2020 perusahaan terpaksa merumahkan sebanyak 10 orang karyawan karena perusahaan tidak mampu lagi untuk memberikan kompensasi penuh kepada seluruh karyawannya, sehingga mengambil keputusan yang berat untuk merumahkan karyawannya hal ini dilakukan karena adanya penyebaran pandemic virus Corona (Covid-19)
PT. Rutan Palembang merupakan merupakan salah satu perusahaan yang bergerak di bidang perdagangan alat-alat pertanian (Tractor Tangan, Tractor Iseki, Mesin Pengering Padi, Agrindo ARM 1000 untuk alat pemroses dari padi beras, Pompa Air khusus Irigasi), produk ini dibuat rangka untuk memenuhi kebutuhan akan pangan di wilayah Indonesia.

Berdasarkan pengamatan peneliti terdapat fenomena masalah disiplin kerja karyawan dimana banyak karyawan yang sering terlambat masuk kerja dan keluar sebelum jam istirahat. Masalah disiplin ini juga dapat dilihat dari absensi karyawan dari tahun 2017, tahun 2018, tahun 2019 dan tahun 2020 pada tabel sebagai berikut :

Tabel .1.3

Rekapitulasi Absensi Karyawan

CV. Rutan Palembang

Tahun 2016

\begin{tabular}{|c|c|c|c|c|c|c|c|c|}
\hline Bulan & $\begin{array}{l}\text { Jlh hari } \\
\text { kerja }\end{array}$ & $\begin{array}{c}\text { Jlh } \\
\text { karyawan }\end{array}$ & $\begin{array}{l}\text { Hadir } \\
\%\end{array}$ & $\begin{array}{c}\text { Tidak } \\
\text { Hadir } \%\end{array}$ & $\begin{array}{l}\text { Izin } \\
\%\end{array}$ & $\begin{array}{c}\text { Sakit } \\
\%\end{array}$ & $\begin{array}{l}\text { Alpa } \\
\%\end{array}$ & Ket \\
\hline Januari & 25 & 26 & 84,62 & 15,38 & 11,54 & 3,84 & 0 & $\begin{array}{l}\mathrm{H}=22, \mathrm{TH}=4, \\
\mathrm{I}=3, \mathrm{~S}=1, \mathrm{~A}=0\end{array}$ \\
\hline Februari & 24 & 26 & 84,62 & 15,38 & 7,69 & 3,85 & 3,84 & $\begin{array}{l}\mathrm{H}=22, \mathrm{TH}=, 4 \\
\mathrm{I}=2, \mathrm{~S}=1, \mathrm{~A}=1\end{array}$ \\
\hline Maret & 25 & 30 & 80 & 20 & 10 & 3,33 & 6,67 & $\begin{array}{l}\mathrm{H}=24, \mathrm{TH}=6, \\
\mathrm{I}=3, \mathrm{~S}=1, \mathrm{~A}=2\end{array}$ \\
\hline April & 26 & 30 & 73,33 & 26,67 & 16,67 & 6,67 & 3,33 & $\begin{array}{l}\mathrm{H}=22, \mathrm{TH}=8, \\
\mathrm{I}=5, \mathrm{~S}=2, \mathrm{~A}=1\end{array}$ \\
\hline Mei & 24 & 29 & 82,76 & 17,24 & 6,90 & 10,34 & 0 & $\begin{array}{l}\mathrm{H}=24, \mathrm{TH}=5, \\
\mathrm{I}=2, \mathrm{~S}=3, \mathrm{~A}=0\end{array}$ \\
\hline Juni & 26 & 28 & 82,14 & 17,86 & 0 & 14,29 & 3,57 & $\begin{array}{l}\mathrm{H}=23, \mathrm{TH}=5, \\
\mathrm{I}=0, \mathrm{~S}=4, \mathrm{~A}=1\end{array}$ \\
\hline Juli & 21 & 30 & 83,33 & 16,67 & 6,67 & 6,67 & 3,33 & $\begin{array}{l}\mathrm{H}=25, \mathrm{TH}=5 \\
\mathrm{I}=2, \mathrm{~S}=2, \mathrm{~A}=1\end{array}$ \\
\hline Agustus & 26 & 32 & 81,25 & 18,75 & 3,13 & 9,37 & 62,5 & $\begin{array}{l}\mathrm{H}=26, \mathrm{TH}=6 \\
\mathrm{I}=1, \mathrm{~S}=3, \mathrm{~A}=2\end{array}$ \\
\hline September & 25 & 32 & 75 & 25 & 6,24 & 9,38 & 9,38 & $\begin{array}{l}\mathrm{H}=24, \mathrm{TH}=8, \\
\mathrm{I}=2, \mathrm{~S}=3, \mathrm{~A}=3\end{array}$ \\
\hline Oktober & 26 & 34 & 76,47 & 23,53 & 11,76 & 8,82 & 2,94 & $\begin{array}{l}\mathrm{H}=26, \mathrm{TH}=8, \\
\mathrm{I}=4, \mathrm{~S}=3, \mathrm{~A}=1\end{array}$ \\
\hline November & 26 & 34 & 82,35 & 17,65 & 0 & 11,76 & 5,89 & $\begin{array}{l}\mathrm{H}=28, \mathrm{TH}=6, \\
\mathrm{I}=0, \mathrm{~S}=4, \mathrm{~A}=2\end{array}$ \\
\hline
\end{tabular}




\begin{tabular}{|c|c|c|c|c|c|c|c|c|}
\hline Desember & 25 & 34 & 70,59 & 29,41 & 11,76 & 11,76 & 4,89 & $\begin{array}{l}\mathrm{H}=24, \mathrm{TH}=10, \\
\mathrm{I}=4, \mathrm{~S}=4, \mathrm{~A}=2\end{array}$ \\
\hline \multicolumn{3}{|c|}{ RATA-RATA } & 874,11 & & & & & $\begin{array}{l}\mathrm{H}=31, \mathrm{TH}=10, \\
\mathrm{I}=4, \mathrm{~S}=4, \mathrm{~A}=2\end{array}$ \\
\hline
\end{tabular}

Sumber: PT. Rutan Tahun 2016

Tabel 1.4

Rekapitulasi Absensi Karyawan

CV. Rutan Palembang

Tahun 2017

\begin{tabular}{|c|c|c|c|c|c|c|c|c|}
\hline Bulan & $\begin{array}{c}\text { Jlh hari } \\
\text { kerja }\end{array}$ & $\begin{array}{c}\text { Jlh } \\
\text { karyawan }\end{array}$ & $\begin{array}{c}\text { Hadir } \\
\%\end{array}$ & $\begin{array}{c}\text { Tidak } \\
\text { Hadir } \% \\
\end{array}$ & $\begin{array}{c}\text { Izin } \\
\%\end{array}$ & $\begin{array}{c}\text { Sakit } \\
\%\end{array}$ & $\begin{array}{c}\text { Alpa } \\
\%\end{array}$ & Ket \\
\hline Januari & 26 & 34 & 70,59 & 29,41 & 8,82 & 11,77 & 8,82 & $\begin{array}{l}\mathrm{H}=24, \mathrm{TH}=10, \\
\mathrm{I}=3, \mathrm{~S}=4, \mathrm{~A}=3\end{array}$ \\
\hline Februari & 23 & 34 & 64,71 & 35,19 & 17,65 & 11,76 & 5,88 & $\begin{array}{l}\mathrm{H}=22, \mathrm{TH}=, 12 \\
\mathrm{I}=6, \mathrm{~S}=4, \mathrm{~A}=2\end{array}$ \\
\hline Maret & 26 & 34 & 82,35 & 17,65 & 8,82 & 2,94 & 5,88 & $\begin{array}{l}\mathrm{H}=28, \mathrm{TH}=6, \\
\mathrm{I}=3, \mathrm{~S}=1, \mathrm{~A}=2\end{array}$ \\
\hline April & 23 & 34 & 83,35 & 17,65 & 5,88 & 5,88 & 5,88 & $\begin{array}{l}\mathrm{H}=28, \mathrm{TH}=6, \\
\mathrm{I}=2, \mathrm{~S}=2, \mathrm{~A}=2\end{array}$ \\
\hline Mei & 24 & 34 & 85,29 & 14,71 & 5,88 & 8,83 & 0 & $\begin{array}{l}\mathrm{H}=29, \mathrm{TH}=5, \\
\mathrm{I}=2, \mathrm{~S}=3, \mathrm{~A}=0\end{array}$ \\
\hline Juni & 20 & 34 & 83,35 & 17,65 & 2,94 & 11,76 & 2,94 & $\begin{array}{l}\mathrm{H}=28, \mathrm{TH}=6, \\
\mathrm{I}=1, \mathrm{~S}=4, \mathrm{~A}=1\end{array}$ \\
\hline Juli & 26 & 34 & 73,53 & 26,47 & 14,71 & 5,88 & 5,88 & $\begin{array}{l}\mathrm{H}=25, \mathrm{TH}=9 \\
\mathrm{I}=5, \mathrm{~S}=2, \mathrm{~A}=2\end{array}$ \\
\hline Agustus & 26 & 32 & 81,25 & 18,75 & 3,12 & 9,38 & 6,25 & $\begin{array}{l}\mathrm{H}=26, \mathrm{TH}=6 \\
\mathrm{I}=1, \mathrm{~S}=3, \mathrm{~A}=2\end{array}$ \\
\hline September & 24 & 32 & 75 & 25 & 6,25 & 9,37 & 9,37 & $\begin{array}{l}\mathrm{H}=24, \mathrm{TH}=8, \\
\mathrm{I}=2, \mathrm{~S}=3, \mathrm{~A}=3\end{array}$ \\
\hline Oktober & 26 & 32 & 81,25 & 18,75 & 6,25 & 9,37 & 3,12 & $\begin{array}{l}\mathrm{H}=26, \mathrm{TH}=6, \\
\mathrm{I}=2, \mathrm{~S}=3, \mathrm{~A}=1\end{array}$ \\
\hline November & 26 & 32 & 87,50 & 12,5 & 0 & 12,5 & 0 & $\begin{array}{l}\mathrm{H}=28, \mathrm{TH}=4, \\
\mathrm{I}=0, \mathrm{~S}=4, \mathrm{~A}=0\end{array}$ \\
\hline Desember & 23 & 32 & 81,25 & 18,75 & 12,50 & 0 & 6,25 & $\begin{array}{l}\mathrm{H}=26, \mathrm{TH}=6, \\
\mathrm{I}=4, \mathrm{~S}=0, \mathrm{~A}=2\end{array}$ \\
\hline \multicolumn{3}{|c|}{ RATA-RATA } & & & & & & $\begin{array}{l}\mathrm{H}=31, \mathrm{TH}=10, \\
\mathrm{I}=4, \mathrm{~S}=4, \mathrm{~A}=2\end{array}$ \\
\hline
\end{tabular}

Sumber: PT. Rutan Tahun 2017 
Tabel 1.5

Rekapitulasi Absensi Karyawan

CV. Rutan Palembang Tahun 2018

\begin{tabular}{|c|c|c|c|c|c|c|c|c|}
\hline Bulan & $\begin{array}{c}\text { Jlh hari } \\
\text { kerja }\end{array}$ & $\begin{array}{c}\text { Jlh } \\
\text { karyawan }\end{array}$ & $\begin{array}{c}\text { Hadir } \\
\%\end{array}$ & $\begin{array}{c}\text { Tidak } \\
\text { Hadir \% }\end{array}$ & $\begin{array}{c}\text { Izin } \\
\%\end{array}$ & $\begin{array}{c}\text { Sakit } \\
\%\end{array}$ & $\begin{array}{c}\text { Alpa } \\
\%\end{array}$ & Ket \\
\hline Januari & 26 & 32 & 87,50 & 12,50 & 9,37 & 3,13 & 0 & $\begin{array}{l}\mathrm{H}=28, \mathrm{TH}=4, \\
\mathrm{I}=3, \mathrm{~S}=1, \mathrm{~A}=0\end{array}$ \\
\hline Februari & 23 & 32 & 87,50 & 12,50 & 6,25 & 3,12 & 3,12 & $\begin{array}{l}\mathrm{H}=28, \mathrm{TH}=4 \\
\mathrm{I}=2, \mathrm{~S}=1, \mathrm{~A}=1\end{array}$ \\
\hline Maret & 26 & 34 & 88,23 & 11,76 & 8,82 & 2,94 & 0 & $\begin{array}{l}\mathrm{H}=30, \mathrm{TH}=4, \\
\mathrm{I}=3, \mathrm{~S}=1, \mathrm{~A}=0\end{array}$ \\
\hline April & 24 & 34 & 85,29 & 14,91 & 14,91 & 0 & 0 & $\begin{array}{l}\mathrm{H}=29, \mathrm{TH}=5, \\
\mathrm{I}=5, \mathrm{~S}=0, \mathrm{~A}=0\end{array}$ \\
\hline Mei & 24 & 34 & 88,24 & 11,76 & 5,88 & 0 & 5,88 & $\begin{array}{l}\mathrm{H}=30, \mathrm{TH}=4, \\
\mathrm{I}=2, \mathrm{~S}=0, \mathrm{~A}=2\end{array}$ \\
\hline Juni & 18 & 37 & 86,49 & 13,51 & 0 & 10,81 & 2,70 & $\begin{array}{l}\mathrm{H}=32, \mathrm{TH}=5, \\
\mathrm{I}=0, \mathrm{~S}=4, \mathrm{~A}=1\end{array}$ \\
\hline Juli & 26 & 37 & 86,49 & 13,51 & 5,40 & 5,40 & 2,71 & $\begin{array}{l}\mathrm{H}=32, \mathrm{TH}=5 \\
\mathrm{I}=2, \mathrm{~S}=2, \mathrm{~A}=1\end{array}$ \\
\hline Agustus & 25 & 36 & 72,22 & 27,88 & 11,11 & 8,33 & 8,33 & $\begin{array}{l}\mathrm{H}=26, \mathrm{TH}=10 \\
\mathrm{I}=4, \mathrm{~S}=3, \mathrm{~A}=3\end{array}$ \\
\hline September & 25 & 36 & 66,67 & 33,33 & 16,67 & 8,33 & 8,33 & $\begin{array}{l}\mathrm{H}=24, \mathrm{TH}=12 \\
\mathrm{I}=6, \mathrm{~S}=3, \mathrm{~A}=3\end{array}$ \\
\hline Oktober & 27 & 36 & 69,44 & 30,56 & 11,11 & 16,67 & 2,78 & $\begin{array}{l}\mathrm{H}=25, \mathrm{TH}=11, \\
\mathrm{I}=4, \mathrm{~S}=6, \mathrm{~A}=1\end{array}$ \\
\hline November & 25 & 36 & 77,78 & 22,22 & 5,56 & 11,10 & 5,56 & $\begin{array}{l}\mathrm{H}=28, \mathrm{TH}=8, \\
\mathrm{I}=2, \mathrm{~S}=4, \mathrm{~A}=2\end{array}$ \\
\hline Desember & 24 & 36 & 66,67 & 33,33 & 8,33 & 13,89 & 11,10 & $\begin{array}{l}\mathrm{H}=24, \mathrm{TH}=12, \\
\mathrm{I}=3, \mathrm{~S}=5, \mathrm{~A}=4\end{array}$ \\
\hline \multicolumn{3}{|c|}{ RATA-RATA } & 80.21 & 19.82 & 8.62 & 6.97 & 4.21 & $\begin{array}{l}\mathrm{H}=31, \mathrm{TH}=10, \\
\mathrm{I}=4, \mathrm{~S}=4, \mathrm{~A}=2\end{array}$ \\
\hline
\end{tabular}

Sumber: PT. Rutan Tahun 2018

Tabel 1.6

Rekapitulasi Absensi Karyawan

CV. Rutan Palembang Tahun 2019

\begin{tabular}{|l|c|c|c|c|c|c|c|c|}
\hline \multicolumn{1}{|c|}{ Bulan } & $\begin{array}{c}\text { Jlh hari } \\
\text { kerja }\end{array}$ & $\begin{array}{c}\text { Jlh } \\
\text { karyawan }\end{array}$ & $\begin{array}{c}\text { Hadir } \\
\%\end{array}$ & $\begin{array}{c}\text { Tidak } \\
\text { Hadir } \%\end{array}$ & $\begin{array}{c}\text { Izin } \\
\%\end{array}$ & $\begin{array}{c}\text { Sakit } \\
\%\end{array}$ & $\begin{array}{c}\text { Alpa } \\
\%\end{array}$ & Ket \\
\hline Januari & 26 & 36 & 86,11 & 13,89 & 11,11 & 2,78 & 0 & $\begin{array}{l}\mathrm{H}=31, \mathrm{~T}=5 \\
\mathrm{I}=4, \mathrm{~S}=1, \mathrm{~A}=0\end{array}$ \\
\hline Februari & 23 & 36 & 88,89 & 11,11 & 2,78 & 0 & 8,33 & $\begin{array}{l}\mathrm{H}=32, \mathrm{~T}=4, \\
\mathrm{I}=1, \mathrm{~S}=0, \mathrm{~A}=3\end{array}$ \\
\hline Maret & 25 & 34 & 100 & 0 & 0 & 0 & 0 & $\begin{array}{l}\mathrm{H}=34, \mathrm{~T}=0, \\
\mathrm{I}=0, \mathrm{~S}=0, \mathrm{~A}=0\end{array}$ \\
\hline April & 23 & 34 & 94,12 & 5,88 & 2,94 & 2,94 & 0 & $\begin{array}{l}\mathrm{H}=32, \mathrm{~T}=2, \\
\mathrm{I}=1, \mathrm{~S}=1, \mathrm{~A}=0\end{array}$ \\
\hline Mei & 24 & 32 & 96,88 & 3,12 & 0 & 3,12 & 0 & $\begin{array}{l}\mathrm{H}=31, \mathrm{~T}=1, \\
\mathrm{I}=0, \mathrm{~S}=1, \mathrm{~A}=0\end{array}$ \\
\hline
\end{tabular}




\begin{tabular}{|c|c|c|c|c|c|c|c|c|}
\hline Juni & 22 & 32 & 87,50 & 12,50 & 6,25 & 6,25 & 0 & $\begin{array}{l}\mathrm{H}=28, \mathrm{~T}=4, \\
\mathrm{I}=2, \mathrm{~S}=2, \mathrm{~A}=0\end{array}$ \\
\hline Juli & 26 & 38 & 84,21 & 15,79 & 10,53 & 2,63 & 2,63 & $\begin{array}{l}\mathrm{H}=32, \mathrm{~T}=6, \\
\mathrm{I}=4, \mathrm{~S}=1, \mathrm{~A}=1\end{array}$ \\
\hline Agustus & 26 & 38 & 92,11 & 7,89 & 7,89 & 0 & 0 & $\begin{array}{l}\mathrm{H}=35, \mathrm{~T}=3, \\
\mathrm{I}=3, \mathrm{~S}=0, \mathrm{~A}=0\end{array}$ \\
\hline September & 25 & 38 & 84,21 & 15,79 & 5,26 & 7,89 & 2,63 & $\begin{array}{l}\mathrm{H}=32, \mathrm{~T}=6, \\
\mathrm{I}=2, \mathrm{~S}=3, \mathrm{~A}=1\end{array}$ \\
\hline Oktober & 26 & 42 & 85,71 & 14,29 & 2,38 & 9,52 & 2,38 & $\begin{array}{l}\mathrm{H}=36, \mathrm{~T}=6, \\
\mathrm{I}=1, \mathrm{~S}=4, \mathrm{~A}=1\end{array}$ \\
\hline November & 25 & 42 & 90,48 & 9,52 & 5,26 & 2,38 & 2,38 & $\begin{array}{l}\mathrm{H}=38, \mathrm{~T}=4, \\
\mathrm{I}=2, \mathrm{~S}=1, \mathrm{~A}=1\end{array}$ \\
\hline Desember & 25 & 42 & 92,86 & 7,14 & 0 & 2,38 & 5,26 & $\begin{array}{l}\mathrm{H}=39, \mathrm{~T}=3, \\
\mathrm{I}=0, \mathrm{~S}=1, \mathrm{~A}=2\end{array}$ \\
\hline \multicolumn{3}{|c|}{ RATA-RATA } & 90.26 & 9.74 & 4.53 & 3.32 & 1.97 & $\begin{array}{l}\mathrm{H}=29, \mathrm{~T}=8, \\
\mathrm{I}=4, \mathrm{~S}=2, \mathrm{~A}=2\end{array}$ \\
\hline
\end{tabular}

Sumber: PT. Rutan Tahun 2019

Tabel 1.7

Rekapitulasi Absensi Karyawan

CV. Rutan Palembang

Tahun 2020

\begin{tabular}{|l|c|c|c|c|c|c|c|l|}
\hline \multicolumn{1}{|c|}{ Bulan } & $\begin{array}{c}\text { Jlh hari } \\
\text { kerja }\end{array}$ & $\begin{array}{c}\text { Jlh } \\
\text { karyawan }\end{array}$ & $\begin{array}{c}\text { Hadir } \\
\%\end{array}$ & $\begin{array}{c}\text { Tidak } \\
\text { Hadir } \%\end{array}$ & $\begin{array}{c}\text { Izin } \\
\%\end{array}$ & $\begin{array}{c}\text { Sakit } \\
\%\end{array}$ & $\begin{array}{c}\text { Alpa } \\
\%\end{array}$ & \multicolumn{1}{|c|}{ Ket } \\
\hline Januari & 25 & 42 & 73,81 & 26,19 & 11,90 & 9,52 & 4,77 & $\begin{array}{l}\mathrm{H}=31, \mathrm{~T}=, 11 \\
\mathrm{I}=5, \mathrm{~S}=4, \mathrm{~A}=2\end{array}$ \\
\hline Februari & 25 & 42 & 88,09 & 11,91 & 2,38 & 7,14 & 2,38 & $\begin{array}{l}\mathrm{H}=37, \mathrm{~T}=5, \\
\mathrm{I}=1, \mathrm{~S}=3, \mathrm{~A}=1\end{array}$ \\
\hline Maret & 25 & 38 & 84,21 & 15,79 & 10,53 & 2,63 & 2,63 & $\begin{array}{l}\mathrm{H}=32, \mathrm{~T}=6, \\
\mathrm{I}=4, \mathrm{~S}=1, \mathrm{~A}=1\end{array}$ \\
\hline April & 25 & 38 & 78,95 & 21,05 & 7,89 & 7,89 & 5,27 & $\begin{array}{l}\mathrm{H}=30, \mathrm{~T}=8, \\
\mathrm{I}=3, \mathrm{~S}=3, \mathrm{~A}=2\end{array}$ \\
\hline Mei & 22 & 34 & 100 & 0 & 0 & 0 & 0 & $\begin{array}{l}\mathrm{H}=34, \mathrm{~T}=0, \\
\mathrm{I}=3, \mathrm{~S}=1, \mathrm{~A}=1\end{array}$ \\
\hline Juni & 25 & 34 & 94,12 & 5,88 & 5,88 & 0 & 0 & $\begin{array}{l}\mathrm{H}=32, \mathrm{~T}=2, \\
\mathrm{I}=2, \mathrm{~S}=0, \mathrm{~A}=0\end{array}$ \\
\hline Juli & 26 & 34 & 97,06 & 2,94 & 0 & 2,94 & 0 & $\begin{array}{l}\mathrm{H}=33, \mathrm{~T}=1, \\
\mathrm{I}=0, \mathrm{~S}=1, \mathrm{~A}=0\end{array}$ \\
\hline Agustus & 24 & 34 & 91,18 & 8,82 & 8,82 & 0 & 0 & $\begin{array}{l}\mathrm{H}=31, \mathrm{~T}=3, \\
\mathrm{I}=3, \mathrm{~S}=0, \mathrm{~A}=0\end{array}$ \\
\hline September & 26 & 32 & 87,50 & 12,50 & 12,50 & 0 & 0 & $\begin{array}{l}\mathrm{H}=28, \mathrm{~T}=4 \\
\mathrm{I}=4, \mathrm{~S}=0, \mathrm{~A}=0\end{array}$ \\
\hline Oktober & 26 & 32 & 90,63 & 9,37 & 3,12 & 3,12 & 3,12 & $\begin{array}{l}\mathrm{H}=29, \mathrm{~T}=3, \\
\mathrm{I}=1, \mathrm{~S}=1, \mathrm{~A}=1\end{array}$ \\
\hline November & 25 & 32 & 84,38 & 15,62 & 6,25 & 0 & 9,37 & $\begin{array}{l}\mathrm{H}=27, \mathrm{~T}=5, \\
\mathrm{I}=2, \mathrm{~S}=0, \mathrm{~A}=3\end{array}$ \\
\hline Desember & 26 & 32 & 87,50 & 12,50 & 6,25 & 3,12 & 3,12 & $\begin{array}{l}\mathrm{H}=28, \mathrm{~T}=4, \\
\mathrm{I}=2, \mathrm{~S}=1, \mathrm{~A}=1\end{array}$ \\
\hline \multicolumn{2}{|r|}{ RATA-RATA } & & 88.12 & 11.88 & 6.29 & 3.03 & 2.56 & $\begin{array}{l}\mathrm{H}=29, \mathrm{~T}=8, \\
\mathrm{I}=4, \mathrm{~S}=2, \mathrm{~A}=2\end{array}$ \\
\hline
\end{tabular}

Sumber: PT. Rutan Tahun 2020 
Hasil pengamatan peneliti menemukan bahwa kinerja karyawan belum maksimal. Hal ini dapat dilihat dari tabel diatas, masih terdapat karyawan yang tidak hadir kerja yang mengindikasikan bahwa ketidakpatuhan pada jam kerja yang ditetapkan oleh perusahaan. Kualitas kerja karyawan masih rendah, hal ini disebabkan dalam melaksanakan pekerjaan seperti tidak memenuhi target yang telah ditentukan.

Kinerja karyawan merupakan hasil kerja yang dicapai seseorang dalam melaksanakan tugas-tugas yang dibebankan kepadanya untuk mencapai target kerja. Kinerja karyawan merupakan salah satu faktor penentu keberhasilan perusahaan atau organisasi dalam mencapai tujuannya. Untuk itu kinerja dari para karyawan harus mendapat perhatian dari para pimpinan perusahaan, sebab menurunnya kinerja dari karyawan dapat mempengaruhi kinerja perusahaan secara keseluruhan.

Berdasarkan uraian diatas peneliti tertarik untuk melakukan penelitian dengan judul "Pengaruh Budaya Organisasi dan Disiplin Kerja Terhadap Kinerja Karyawan PT. Rutan Palembang”.

\subsection{Perumusan Masalah}

masalah $\begin{gathered}\text { Berdasarkan latar belakang } \\ \text { telah diuraikan }\end{gathered}$ sebelumnya, maka yang menjadi rumusan masalah dalam penelitian ini sebagai berikut :

1. Apakah budaya organisasi dan disiplin kerja berpengaruh secara parsial terhadap kinerja karyawan pada PT. Rutan Palembang?

2. Apakah budaya organisasi dan disiplin kerja berpengaruh secara simultan terhadap kinerja karyawan pada PT. Rutan Palembang?

\section{TINJAUAN PUSTAKA \\ 2.1. Budaya Organisasi \\ 2.1.1 Pengertian Budaya}

Suatu keberhasilan kerja, berakar pada nilai-nilai yang dimiliki dan perilaku yang menjadi kebiasaannya. Nilainilai tersebut bermula dari adat kebiasaan, agama, norma dan kaidah yang menjadi keyakinannya menjadi kebiasaan dalam perilaku kerja atau organisasi. Nilai-nilai yang telah menjadi kebiasaan tersebut dinamakan budaya. Oleh karena budaya dikaitkan dengan mutu atau kualitas kerja, maka dinamakan budaya kerja

$$
\text { Edy Sutrisno (2012:12), }
$$

mendefinisikan budaya organisasi sebagai perangkat sistem nilai-nilai (values), keyakinan-keyakinan (beliefs), asumsi- asumsi (assumptions), atau norma- norma yang telah lama berlaku, disepakati san diikuti oleh para anggota suatu organisasi sebagai pedoman perilaku dan pemecahan masalah-masalah organisasinya. Budaya organisasi juga disebut budaya perusahaan, yaitu seperangkat nilai-nilai atau norma-norma yang telah relatif lama berlakunya, dianut bersama oleh para anggota organisasi (karyawan) sebagai norma perilaku dalam menyelesaikan masalahmasalah organisasi (perusahaan).

Hal yang sama juga diungkapkan oleh Mangkunegara (2012: 113) yang menyatakan bahwa budaya organisasi adalah seperangkat asumsi atau sistem keyakinan, nilai-nilai, dan norma yang dikembangkan dalam organisasi yang dijadikan pedoman tingkah laku bagi anggota-anggotanya untuk mengatasi masalah adaptasi eksternal dan internal.

Menurut Turner dalam Wibowo (2016:258) budaya organisasi adalah norma-norma perilaku, sosial, dan moral yang mendasari setiap tindakan dalam organisasi dan dibentuk oleh 
kepercayaan, sikap, dan prioritas anggotanya.

Budaya yang kuat dan positif sangat berpengaruh terhadap perilaku dan efektifitas kinerja perusahaan karena menimbulkan antara lain:

1. Nilai-nilai kunci yang saling menjalin, tersosialisasikan, menginternalisasi, menjiwai para anggota, dan merupakan kekuatan yang tidak tampak;

2. Perilaku karyawan secara tak disadari terkendali dan terkoordinasi oleh kekuatan yang informal atau tidak tampak;

3. Para anggota merasa komit dan loyal pada organisasi

4. Adanya musyawarah dan kebersamaan dalam hal-hal yang berarti sebagai bentuk partisipasi, pengakuan dan penghormatan kepada karyawan;

5. Semua kegiatan berorientasi kepada misi atau tujuan organisasi;

6. Para karyawan merasa senang, karena diakui dan dihargai martabat dan kontribusinya;

7. Adanya koordinasi, integrasi, dan konsistensi yang menstabilkan kegiatan-kegiatan perusahaan;

8. Berpengaruh kuat terhadap organisasi dalam tiga aspek: pengarahan perilaku dan kinerja organisasi, penyebarannya pada para anggota organisasi, dan kekuatannya yaitu menekan para anggota untuk melaksanakan nilai-nilai budaya;

9. Budaya berpengaruh terhadap perilaku individual maupun kelompok.

\subsubsection{Dimensi dan Indikator Budaya Organisasi}

Ada tujuh karakteristik utama

yang secara keseluruhan merupakan indicator budaya organisasi, menurut
Robbins dan Judge dalam (Wibowo:2015:) adalah sebagai berikut:

1. Inovasi dan keberanian mengambil resiko

Sejauh mana karyawan didorong untuk bersikap inovatif dan berani mengambil resiko.

2. Perhatian pada hal-hal rinci

Sejauh mana karyawan diharapkan menjalankan presisi, analisis dan perhatian pada hal-hal detail.

3. Orientasi hasil kerja

Sejauh mana manajemen berfokus lebih pada hasil ketimbang pada teknik dan proses yang digunakan untuk mencapai hasil tersebut.

4. Orientasi pada anggota organisasi

Sejauh mana keputusan-keputusan manajemen mempertimbangkan efek dari hasil tersebut atas manusia yang ada dalam organisasi ketimbang pada individu-individu.

5. Orientasi tim

Sejauh mana kegiatan-kegiatan

kerja diorganisasi pada tim ketimbang individu-individu.

6. Keagresifan

Sejauh mana orang bersikap agresif dan kompetitif ketimbang santai dan hanya diam saja.

7. Stabilitas

Sejauh mana kegiatan-kegiata organisasi menekankan

dipertahankannya status quo dalam perbandingan dengan pertumbuhan

\subsection{Disiplin kerja}

\subsubsection{Pengertian Disiplin Kerja}

Kedisiplinan merupakan fungsi operasional manajemen sumber daya manusia yang terpenting karena semakin baik disiplin kerja pegawai, semakin baik kinerja yang dapat dicapai. Tanpa disiplin yang baik, sulit bagi organisasi untuk mencapai hasil yang optimal. 
Kedisiplinan merupakan faktor yang utama yang diperlukan sebagai alat peringatan terhadap pegawai yang tidak mau berubah sifat dan perilakunya. Sehingga seorang pegawai dikatakan memiliki disiplin yang baik jika pegawai tersebut memiliki rasa tanggung jawab terhadap tugas yang diberikan kepadanya.

Berikut adalah pengertianpengertian disiplin kerja menurut para ahli diantaranya yaitu Menurut Hasibuan (2016:444) bahwa: "Disiplin kerja adalah kesadaran dan kerelaan seseorang dalam menaati semua peraturan perusahaan dan norma-norma sosial yang berlaku." Menurut Rivai (2012:244) bahwa: "Disiplin kerja adalah suatu alat yang dipergunakan para manajer untuk berkomunikasi dengan karyawan agar mereka bersedia untuk mengubah suatu perilaku serta sebagai suatu upaya untuk meningkatkan kesadaran dan kesedian seorang dalam memenuhi segala peraturan perusahaan."

Dari beberapa pengertian disiplin kerja yang dikemukakan oleh beberapa ahli dapat disimpulkan bahwa disiplin kerja adalah sikap kesadaran, kerelaan dan kesedian seseorang dalam mematuhi dan menaati peraturan dan norma-norma sosial yang berlaku di lingkungan sekitarnya.

\subsubsection{Dimensi Disiplin Kerja}

Rivai (2015: 44) menjelaskan bahwa disiplin kerja memiliki beberapa komponen seperti:

1. Kehadiran.

Hal ini menjadi indikator yang mendasar untuk mengukur kedisiplinan, dan biasanya karyawan yang memiliki disiplin kerja rendah terbiasa untuk terlambat dalam bekerja. Karyawan harus datang ke kantor teratur dan tepat waktu. Ketepatan waktu adalah hal keadaan tepat tidak ada selisih sedikitpun bila waktu yang ditentukan tiba. Ketidakhadiran seorang karyawan akan berpengaruh terhadap produktivitas kerja, sehingga instansi atau lembaga tidak bisa mencapai tujuan secara optimal.

2. Ketaatan pada peraturan kerja.

Karyawan yang taat pada peraturan kerja tidak akan melalaikan prosedur kerja, selalu mengikuti pedoman kerja yang ditetapkan oleh perusahaan, berpakaian rapi, dan menaati tata tertib yang tertulis dan tidak tertulis yang dibuat oleh perusahaan.

3. Ketaatan pada standar kerja.

Hal ini dapat dilihat melalui besarnya tanggung jawab karyawan terhadap tugas yang diamanahkan kepadanya. Karyawan harus mencapai standar kerja yang telah ditentukan oleh perusahaan.

4. Tingkat kewaspadaan tinggi.

Karyawan memiliki kewaspadaan tinggi akan selalu berhati-hati, penuh perhitungan dan ketelitian dalam bekerja sehingga memperkecil kesalahan yang dilakukan dalam bekerja, serta selalu menggunakan sesuatu secara efektif dan efisien.

5. Bekerja etis.

Beberapa karyawan mungkin melakukan tindakan yang tidak sopan ke pelanggan atau terlibat dalam tindakan yang tidak pantas. Hal ini merupakan salah satu bentuk tindakan indisipliner, sehingga bekerja etis sebagai salah satu wujud dari disiplin kerja karyawan.

\subsection{Kinerja}

\subsubsection{Pengertian Kinerja}

Kinerja merupakan suatu fungsi

dari motivasi dan kemampuan untuk menyelesaikan tugas atau pekerjaan.Seseorang sepatutnya memiliki 
derajat kesediaan dan tingkat kemampuan tertentu. Kesediaan dan keterampilan seseorang tidaklah cukup efektif untuk mengerjakan sesuatu tanpa pemahaman yang jelas tentang apa yang akan dikerjakan dan bagaimana mengerjakan.

Kinerja merupakan perilaku nyata yang ditampilkan setiap orang sebagai prestasi kerja yang dihasilkan oleh pegawai sesuai dengan perannya dalam instansi. Kinerja karyawan merupakan suatu hal yang sangat penting dalam upaya instansi untuk mencapai tujuan. Instansi umumnya mendasarkan perencanaan tujuan yang hendak dicapai di masa depan dengan perilaku yang diharapkan dari keseluruhan personel mewujudkan tujuan tersebut.

kinerja $\begin{array}{crr}\text { Tujuan } & \text { utama } & \text { penilaian } \\ \text { pegawai } & \text { adalah } & \text { untuk }\end{array}$ memotivasikan karyawan dalam mencapai sasaran operasi dan dalam memenuhi standar perilaku yang telah ditetapkan sebelumnya. Berikut ini adalah beberapa pengertian kinerja menurut para ahli : Menurut Bernadin dan Russel yang dikutip Gomes Lardoso Faustino (2010;135): “ Kinerja adalah outcome yang dihasilkan dari fungsi suatu pekerjaan tertentu atau kegiatan selama satu periode tertentu."

Kinerja merupakan hasil dan keluaran yang dihasilkan oleh seorang pegawai sesuai dengan perannya dalam organisasi dalam suatu periode tertentu. Kinerja pegawai yang baik adalah salah satu faktor yang sangat penting dalam upaya instansi untuk meningkatan produktivitas. Kinerja merupakan indikator dalam menentukan bagaimana usaha untuk mencapai tingkat produktivitas yang tinggi dalam suatu organisasi atau instansi.

\subsubsection{Indikator Kinerja}

Indikator untuk mengukur kinerja karyawan secara individu ada enam indikator, yaitu Robbins dalam Mangkunegara (2015:260):

1) Kualitas., Kualitas kerja diukur dari persepsi karyawan terhadap kualitas pekerjaan yang dihasilkan serta kesempurnaan tugas terhadap keterampilan dan kemampuan karyawan.

2) Kuantitas., merupakan jumlah yang dihasilkan dinyatakan dalam istilah seperti jumlah unit, jumlah siklus aktivitas yang diselesaikan.

3) Ketepatan waktu, merupakan tingkat aktivitas diselesaikan pada awal waktu yang dinyatakan, dilihat dari sudut koordinasi dengan hasil output serta memaksimalkan waktu yang tersedia untuk aktivitas lain.

4) Efektivitas. merupakan tingkat penggunaan sumber daya organisasi (tenaga, uang, teknologi, bahan baku) dimaksimalkan dengan maksud menaikkan hasil dari setiap unit dalam penggunaan sumber daya.

5) Kemandirian, merupakan tingkat seorang karyawan yang nantinya akan dapat menjalankan fungsi kerjanya Komitmen kerja. Merupakan suatu tingkat dimana karyawan mempunyai komitmen kerja dengan instansi dan tanggung jawab karyawan terhadap kantor. 


\subsection{Kerangka Fikir}

\section{Gambar 1}

Kerangka Fikir

\section{Budaya Organisasi (X1)}

1. Inovasi dan keberanian mengambil resiko

2. Perhatian pada hal-hal rinci

3. Orientasi hasil kerja

4. Orientasi pada anggota organisasi

5. Orientasi tim

6. Keagresifan

7. Stabilitas

(Wibowo, 2015)

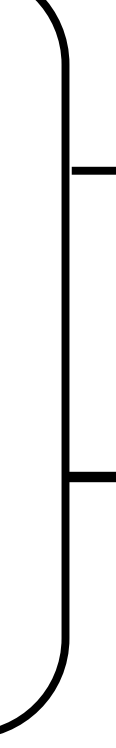

Kinerja (Y)

1. Kualitas

2. Kuantitas

3. Ketepatan Waktu

4. Efektivitas

5. Kemandirian

(Mangkunegara, 2015:260)

1. Kehadiran

2. Ketaatan Pada Peraturan Kerja

3. Ketaatan Pada Standar Kerja

4. Tingkat Kewaspadaan Tinggi

5. Bekerja Etis

(Rivai, 2015:44) 


\subsection{Hipotesis}

Hipotesis dalam penelitian ini adalah :

Hipotesis 1

1. Ada pengaruh budaya organisasi dan disiplin kerja secara parsial terhadap kinerja karyawan Pada PT. Rutan Palembang

2. Tidak ada pengaruh budaya organisasi dan disiplin kerja secara parsial terhadap kinerja karyawan Pada PT. Rutan Palembang

Hipotesis 2

1. Ada pengaruh budaya organisasi dan disiplin kerja secara simultan terhadap kinerja karyawan Pada PT. Rutan Palembang

2. Tidak ada pengaruh budaya organisasi dan disiplin kerja secara simultan terhadap kinerja karyawan Pada PT. Rutan Palembang

\section{METODOLOGI PENELITIAN}

\subsection{Ruang Lingkup Penelitian}

Agar penelitian ini terarah dan tidak menyimpang dari permasalahan maka ruang lingkup penelitian ini adalah masalah budaya kerja dan disiplin kerja terhadap kinerja karyawan.

\subsection{Desain Penelitian}

Desain penelitian ini adalah penelitian asosiatif kausal dengan menggunakan pendekatan kuantitatif. Penelitian asosiatif kausal adalah penelitian yang bertujuan untuk mengetahui pengaruh antara dua variabel atau lebih (Umar, 2012:34). Penelitian ini menjelaskan hubungan memengaruhi dan dipengaruhi dari variable- variabel yang akan diteliti. Adapun pendekatan yang digunakan pada penelitian ini adalah pendekatan kuantitatif karena data yang akan digunakan untuk menganalisis hubungan antar variabel dinyatakan dengan angka atau skala numerik. Adapun variabel yang akan diteliti variabel budaya organisasi sebagai $\mathrm{X}_{1}$ dan variabel disiplin kerja sebagai $\mathrm{X}_{2}$ dan kinerja karyawan sebagai $\mathrm{Y}$.

\subsection{Teknik Analisis}

\subsubsection{Uji Instrumen Data}

a. Uji Validitas dan Reliabilitas Data

Validitas menunjukkan seberapa nyata pengujian mengukur apa yang harusnya diukur (Situmorang et al, 2015:32). Uji validitas dilakukan untuk menguji data yang didapat apakah valid atau tidak dengan alat ukur yang digunakan yaitu dengan menggunakan responden sebagai sampel penelitian. Uji Validitas dan reliabilitas dilakukan untuk menguji apakah angket (kuesioner) yang disebarkan layak untuk dijadikan instrumen penelitian. Hal ini dilakukan agar data-data yang diperoleh valid dan reliabel.

\section{b. Reliabilitas}

Reliabilitas menunjukkan pada suatu pengertian bahwa instrumen cukup dapat dipercaya untuk dapat dipergunakan sebagai alat pengumpulan data karena instrumen sudah baik (Situmorang dkk, 2015). Hasil suatu pengukuran dapat dipercaya apabila dalam beberapa kali pelaksanaan pengukuran terhadap subjek yang sama diperoleh hasil yang relatif sama, artinya mempunyai konsistensi pengukuran yang baik, dan suatu konstruk atau variabel dikatakan reliabel apabila memiliki Cronbach Alpha>0,60 Pengujian realibilitas instrumen menggunakan pengujian satu skor pada taraf signifikan $5 \%$. Pengujian validitas dilakukan dengan menggunakan program SPSS versi 24,00. 


\subsubsection{Analisis Desrkiptif Statistik a. Koefesien Diterminasi}

Untuk mengetahui seberapa besar kemampuan variabel independen menjelaskan variabel dependen. Semakin besar nilai koefisien determinasi, maka semakin baik kemampuan variabel bebas menerangkan variabel terikat. Jika determinasi $\left(\mathrm{r}^{2}\right)$ semakin besar atau mendekati satu, maka dapat dikatakan bahwa variabel bebas semakin besar menjelaskan variabel terikat. Koefisien determinasi $\left(\mathrm{r}^{2}\right)$ pada intinya mengukur seberapa jauh kemampuan model dalam menerangkan variasi variabel dependen. Nilai koefisien determinasi adalah antara nol dan satu. Nilai $r^{2}=$ yang kecil berarti kemampuan variabel-variabel independen dalam menjelaskan variasi variabel dependen amat terbatas

$$
\mathrm{r}^{2}=\frac{\left(\mathrm{n}\left(\sum X \mathrm{Y}^{2}\right)-\left(\sum X Y\right)^{2}\right.}{\left(\mathrm{n}\left(\sum \mathrm{X}^{2}\right)-\left(\sum \mathrm{X}\right)^{2}\left(\mathrm{n}\left(\sum \mathrm{Y}\right)-\left(\sum \mathrm{Y}\right)^{2}\right.\right.}
$$

\section{b. Uji Regresi Berganda}

Analisis regresi linier berganda adalah pengaruh secara linear antara dua atau lebih variabel independen $\left(\mathrm{X}_{1}, \mathrm{X}_{2}, \ldots \mathrm{X}_{\mathrm{n}}\right)$ dengan variabel dependen $(\mathrm{Y})$. Analisis ini untuk mengetahui arah pengaruh antara variabel independen dengan variabel dependen apakah masing-masing variabel independent berhubungan positif atau negatif dan untuk memprediksi nilai dari variabel dependen apabila nilai variabel independen mengalami kenaikan atau penurunan dengan persamaan sebagai berikut :

$$
\begin{aligned}
& \mathbf{Y}=\mathbf{a}+\mathbf{b}_{1} \mathbf{X}_{\mathbf{1}}+\mathbf{b}_{2} \mathbf{X}_{\mathbf{2}}+\mathbf{e} \\
& \text { Dimana: } \\
& \mathrm{Y}=\text { Kinerja } \\
& a=\text { Konstanta } \\
& b_{1}, b_{2}=\text { Koefesien regresi } \\
& X_{1}=\text { Budaya organisasi } \\
& X_{2}=\text { Disiplin kerja }
\end{aligned}
$$

$$
\mathrm{e} \quad=\text { Standart Error }
$$

\section{c. Pengujian hipotesis (Uji F danT)}

1. Uji $F$

Uji ini digunakan untuk mengetahui pengaruh bersama-sama variabel bebas terhadap varibel terikat. Dimana $\mathrm{F}_{\text {hitung }}>$ $\mathrm{F}_{\text {tabel, maka }} \mathrm{H}_{\mathbf{1}}$ diterima atau secara bersama-sama variabel bebas dapat menerangkan variabel terikatnya secara serentak. Sebaliknya apabila $F_{\text {hitung }}<F_{\text {tabel }}$, maka $\mathrm{H}_{0}$ diterima atau secara bersama-sama variabel bebas tidak memiliki pengaruh terhadap variabel terikat. Untuk mengetahui signifikan atau tidak pengaruh secara bersama-sama variabel bebas terhadap variabel terikat maka digunakan probability sebesar 5\% $(\alpha=0,05)$. Jika sig > $\alpha(0,05)$, maka $\mathrm{H}_{0}$ diterima $\mathrm{H}_{1}$ ditolak. Jika sig < $\alpha$ $(0,05)$, maka $\mathrm{H}_{0}$ ditolak $\mathrm{H}_{1}$ diterima.

Adapun rumus uji f digunakan rumus :

$$
\mathrm{f}=\frac{\mathrm{r}^{2} /(\mathrm{k}-1)}{1-\mathrm{r}^{2} / n-k}
$$

\section{Uji T}

Sedangkan Uji $\mathrm{T}$ digunakan untuk mengetahui apakah masing- masing variabel bebasnya secara sendiri-sendiri berpengaruh secara signifikan terhadap variabel terikatnya. Dimana $\mathrm{T}_{\text {tabel }}>\mathrm{T}_{\text {hitung, }} \mathrm{H}_{0}$ diterima. Dan jika $\mathrm{T}_{\text {tabel }}<\mathrm{T}_{\text {hitung, maka } \mathrm{H}_{1}}$ diterima, begitupun jika sig $>\alpha \dot{\alpha}(0,05)$, maka $\mathrm{H}_{0}$ diterima $\mathrm{H}_{1}$ ditolak dan jika sig $<\dot{\alpha}$ $(0,05)$, maka $\mathrm{H}_{0}$ ditolak $\mathrm{H}_{1}$ diterima.

Untuk menghitung nilai nilai $t_{\text {hitung }}$ untuk variabel bebas (pengawasan kepatuhan internal dan komitmen organisasi ) dapat digunakan rumus sebagai berikut :

$$
\mathrm{t}=\frac{\mathrm{r} \sqrt{ }(\mathrm{n}-2)}{\sqrt{1-\mathrm{r}^{2}}}
$$




\section{HASIL PENELITIAN DAN PEMBAHASAN}

\subsection{Uji Instrumen Data}

\section{a. Uji Validasi Data}

1. Validasi Budaya organisasi $\left(\mathrm{X}_{1}\right)$

Hasil dari validitas yang telah dilakukan menunjukkan bahwa dari seluruh item (14 butir) pertanyaan dalam kuesioner yang digunakan sebagai alat ukur ternyata semua item pertanyaan memiliki nilai diatas batas kritis yang ditentukan, sehingga dinyatakan valid. Secara terperinci nilai dari masing-masing item dapat ditunjukkan tabel berikut ini :

Tabel 4.7

Hasil Uji Validitas Budaya Organisasi $\left(\mathrm{X}_{1}\right)$

\begin{tabular}{|c|c|c|}
\hline $\begin{array}{c}\text { Butir } \\
\text { pertanyaan }\end{array}$ & $\begin{array}{c}\text { Corrected Item total } \\
\text { Correlation }\end{array}$ & Status \\
\hline Butir 1 & 0.633 & Valid \\
\hline Butir 2 & 0.594 & Valid \\
\hline Butir 3 & 0.784 & Valid \\
\hline Butir 4 & 0.641 & Valid \\
\hline Butir 5 & 0.792 & Valid \\
\hline Butir 6 & 0.700 & Valid \\
\hline Butir 7 & 0.641 & Valid \\
\hline Butir 8 & 0.792 & Valid \\
\hline Butir 9 & 0.628 & Valid \\
\hline Butir 10 & 0.611 & Valid \\
\hline Butir 11 & 0.417 & Valid \\
\hline Butir 12 & 0.574 & Valid \\
\hline Butir 13 & 0.684 & Valid \\
\hline Butir 14 & 0.769 & Valid \\
\hline
\end{tabular}

Sumber : Hasil olah data SPSS Ver 24,0

2. Validasi Variabe Disiplin Kerja

Tabel 4.8

Hasil Uji Validitas disiplin kerja $\left(\mathrm{X}_{2}\right)$

\begin{tabular}{|c|c|c|}
\hline $\begin{array}{c}\text { Butir } \\
\text { pertanyaan }\end{array}$ & $\begin{array}{c}\text { Corrected Item total } \\
\text { Correlation }\end{array}$ & Status \\
\hline Butir 1 & 0.580 & Valid \\
\hline Butir 2 & 0.543 & Valid \\
\hline Butir 3 & 0.735 & Valid \\
\hline Butir 4 & 0.714 & Valid \\
\hline Butir 5 & 0.739 & Valid \\
\hline Butir 6 & 0.703 & Valid \\
\hline Butir 7 & 0.714 & Valid \\
\hline Butir 8 & 0.698 & Valid \\
\hline Butir 9 & 0.639 & Valid \\
\hline Butir 10 & 0.658 & Valid \\
\hline
\end{tabular}

Sumber : Hasil olah data SPSS Ver 24,0 
3. Validasi Variabel Kinerja (Y)

Tabel 4.9

Hasil Uji Validitas Kinerja (Y)

\begin{tabular}{|c|c|c|}
\hline $\begin{array}{c}\text { Butir } \\
\text { pertanyaan }\end{array}$ & $\begin{array}{c}\text { Corrected Item total } \\
\text { Correlation }\end{array}$ & Status \\
\hline Butir 1 & 0.591 & Valid \\
\hline Butir 2 & 0.539 & Valid \\
\hline Butir 3 & 0.731 & Valid \\
\hline Butir 4 & 0.793 & Valid \\
\hline Butir 5 & 0.718 & Valid \\
\hline Butir 6 & 0.626 & Valid \\
\hline Butir 7 & 0.706 & Valid \\
\hline Butir 8 & 0.810 & Valid \\
\hline Butir 9 & 0.660 & Valid \\
\hline Butir 10 & 0.622 & Valid \\
\hline
\end{tabular}

Sumber : Hasil olah data SPSS Ver 24,0

\section{b. Uji Reliabilitas Data}

Tabel 4.10

Hasil Uji Reliabilitas

\begin{tabular}{|l|c|l|}
\hline \multicolumn{1}{|c|}{ Variabel } & $\begin{array}{c}\text { Alpha } \\
\text { Cronbach }(\boldsymbol{\alpha})\end{array}$ & Status \\
\hline Budaya Organisasi & 0,926 & Reliabel \\
\hline Disiplin Kerja & 0,909 & Reliabel \\
\hline Kinerja & 0,911 & Reliabel \\
\hline
\end{tabular}

Sumber : Hasil olah data SPSS Ver 24,0

\subsection{Analisis Deskriptif Statistik}

\section{a. Koefesien Diterminasi}

Tabel 4.11

Koefesien Diterminasi

\begin{tabular}{|c|c|c|c|c|}
\hline \multicolumn{5}{|c|}{$\begin{array}{l}\text { Model Summary } \\
\text { Model Summary }\end{array}$} \\
\hline Model & $\mathrm{R}$ & R Square & $\begin{array}{l}\text { Adjusted R } \\
\text { Square }\end{array}$ & $\begin{array}{l}\text { Std. Error of the } \\
\text { Estimate }\end{array}$ \\
\hline 1 & $.642^{a}$ & .412 & ,747 & 6.57830 \\
\hline
\end{tabular}

Sumber : Hasil olah data SPSS V 22,0

a. $\quad \mathrm{R}$ Square $\left(\mathrm{R}^{2}\right)$ atau kuadrat dari $\mathrm{R}$, yaitu menunjukan nilai koefesien determinasi. Angka ini akan diubah ke bentuk persen yang artinya persentase sumbangan pengaruh variabel independent terhadap variabel dependent. Nilai $R^{2}$ sebesar 0,412 artinya persentase sumbangan budaya organisasi dan disiplin kerja terhadap kinerja sebesar 41,2\%, 
sedangkan sisanya 58,8\% dipengaruhi oleh variabel lain yang tidak dimasukkan dalam penelitian ini.

\section{b. Uji Regresi Berganda}

Tabel 4.12

Koefesien Regresi

\begin{tabular}{|c|c|c|c|c|c|c|}
\hline \multicolumn{7}{|c|}{ Coefficients $^{a}$} \\
\hline \multirow{2}{*}{\multicolumn{2}{|c|}{ Model }} & \multicolumn{2}{|c|}{ Unstandardized Coefficients } & $\begin{array}{l}\text { Standardized } \\
\text { Coefficients }\end{array}$ & \multirow[b]{2}{*}{$\mathrm{t}$} & \multirow[b]{2}{*}{ Sig. } \\
\hline & & $\mathrm{B}$ & Std. Error & Beta & & \\
\hline \multirow[t]{3}{*}{1} & (Constant) & 8.476 & 10.285 & & 7.769 & .010 \\
\hline & $\mathrm{X} 1$ & .807 & .776 & .406 & 3.551 & .000 \\
\hline & $\mathrm{X} 2$ & .504 & .489 & .279 & 2.212 & .001 \\
\hline
\end{tabular}

a. Dependent Variable: $\mathrm{Y}$

Sumber : Hasil olah data SPSS V 24,0

Hasil regresinya adalah sebagai berikut :

$\mathrm{Y}=\alpha+\mathrm{b}_{1} \mathrm{X}_{1}+\mathrm{b}_{2} \mathrm{X}_{2}$

$\mathrm{Y}=8,476+0,807 \mathrm{X}_{1}+0,504 \mathrm{X}_{2}$

Dimana :

Memperhatikan persamaan regresi

linier berganda tersebut, diketahui nilai

a. Angka konstanta dari unstandardized coefficient yang dalam penelitian ini sebesar 8,476 angka ini berupa angka konstanta yang mempunyai arti : jika variabel budaya

organisasi dan disiplin kerja 0 , maka jumlah kinerja sebesar 8,476

b Angka koefisien regresi $\mathrm{X}_{1}$ sebesar 0,807. Angka tersebut mempunyai arti bahwa setiap penambahan $1 \%$ budaya organisasi maka kinerja akan meningkat sebesar 0,807\%

c. Angka koefesien regresi $\mathrm{X}_{2}$ sebesar 0,504 . Angka tersebut mempunyai arti bahwa setiap penambahan $1 \%$ disiplin kerja, maka kinerja akan meningkat sebesar 0,504\%

\section{c. Uji Signifikansi Secara Individu (Uji t)}

Tabel 4.13

Koefesien Regresi

\begin{tabular}{|c|c|c|c|c|c|c|}
\hline \multicolumn{7}{|c|}{ Coefficients $^{a}$} \\
\hline \multirow{2}{*}{\multicolumn{2}{|c|}{ Model }} & \multicolumn{2}{|c|}{ Unstandardized Coefficients } & \multirow{2}{*}{$\begin{array}{c}\text { Standardized } \\
\text { Coefficients } \\
\text { Beta }\end{array}$} & \multirow[b]{2}{*}{$t$} & \multirow[b]{2}{*}{ Sig. } \\
\hline & & $\mathrm{B}$ & Std. Error & & & \\
\hline \multirow[t]{3}{*}{1} & (Constant) & 8.476 & 10.285 & & 7.769 & .010 \\
\hline & $\mathrm{X} 1$ & .807 & .776 & .406 & 3.551 & .000 \\
\hline & $\mathrm{X} 2$ & .504 & .489 & .279 & 2.212 & .002 \\
\hline
\end{tabular}

a. Dependent Variable: $\mathrm{Y}$

Sumber : Hasil olah data SPSS V 24,0

a. Pengujian variabel budaya organisasi

$\left(b_{1}\right)$ dengan hipotesis:

$\mathrm{H}_{\mathrm{o}}=$ koefiesien regresi (budaya organisasi) secara parsial berpengaruh terhadap kinerja

$$
\mathrm{H}_{1}=\text { koefiesien regresi (budaya }
$$
organisasi) secara parsial tidak berpengaruh terhadap kinerja. Berdasarkan hasil dari output $t_{\text {hitung }}$ diperoleh sebesar 3,551 
Untuk mencari $\mathrm{t}$ tabel pada signifikansi 0,05 dengan derajat kebebasan

$\mathrm{df}=\mathrm{n}-\mathrm{k}-1$ atau $32-2-1=2,045$ maka diperoleh nilai untuk $t$ tabel sebesar 2,045. Karena $\mathrm{t}_{\text {hitung }}\left(3,551>\mathrm{t}_{\text {tabel }}(2,045)\right.$, maka $\mathrm{H}_{0}$ diterima, , $\mathrm{H}_{1}$ ditolak artinya bahwa budaya organisasi secara parsial berpengaruh terhadap kinerja.

b. Pengujian variabel disiplin kerja $\left(b_{2}\right)$ dengan hipotesis :

$\mathrm{H}_{\mathrm{o}}=$ koefiesien regresi (disiplin kerja) secara parsial berpengaruh terhadap kinerja

$\mathrm{H}_{1}=$ koefiesien regresi (disiplin kerja) secara parsial tidak berpengaruh terhadap kinerja

Berdasarkan hasil dari output $t$ hitung diperoleh sebesar 2,212

Untuk mencari $\mathrm{t}$ tabel pada signifikansi

0,05 dengan derajat kebebasan $\mathrm{df}=\mathrm{n}-\mathrm{k}-1$ atau $32-2-1=29$ maka diperoleh nilai untuk $\mathrm{t}$ tabel sebesar 2,045. Karena $\mathrm{t}$ hitung $(2,212)>\mathrm{t}$ tabel $(2,045)$, maka $\mathrm{H}_{\mathrm{o}}$ diterima, $\mathrm{H}_{1}$, ditolak artinya bahwa disiplin kerja secara parsial berpengaruh terhadap kinerja

c. Uji Signifikansi Secara Bersama-sama ( uji f)

Uji-F atau uji koefesien regresi secara bersama-sama digunakan untuk mengetahui apakah secara bersama-sama variabel independen berpengaruh signifikan terhadap variabel dependen. Dalam hal ini untuk mengetahui apakah variabel budaya organisasi dan disiplin kerja berpengaruh secara signifikan atau tidak terhadap kinerja . Pengujian menggunakan tingkat signifikansi 0,05 .

Tabel 4.14

\begin{tabular}{|c|c|c|c|c|c|c|}
\hline \multicolumn{7}{|c|}{ ANOVA $^{a}$} \\
\hline & & Sum of Squares & df & Mean Square & $\mathrm{F}$ & Sig. \\
\hline \multirow[t]{3}{*}{1} & Regression & 25.926 & 2 & 12.963 & 6.300 & $.000^{\mathrm{b}}$ \\
\hline & Residual & 1254.949 & 29 & 43.274 & & \\
\hline & Total & 1280.875 & 31 & & & \\
\hline
\end{tabular}

a. Dependent Variable: $Y$

b. Predictors: (Constant), X2, X1

$\mathrm{H}_{0}: \mathrm{b}_{1}, \mathrm{~b}_{2}=0$, artinya secara bersamasama terdapat pengaruh yang positif dan signifikan dari variabel bebas $\left(\mathrm{X}_{1}, \mathrm{X}_{2}\right)$ yaitu berupa budaya organisasi dan disiplin kerja terhadap kinerja karyawan sebagai variabel terikat (Y).

$\mathrm{H}_{1}: \mathrm{b}_{1}, \mathrm{~b}_{2} \neq 0$, artinya secara bersama-sama tidak terdapat pengaruh yang positif dan signifikan dari variabel bebas $\left(\mathrm{X}_{1}, \mathrm{X}_{2}\right)$ yaitu berupa budaya organisasi dan disiplin kerja terhadap kinerja karyawan sebagai variabel terikat (Y).

Berdasarkan hasil dari output $\mathrm{F}$ hitung diperoleh nilai sebesar 6,300

Untuk mencari $F$ tabel pada signifikansi 0,05 dengan derajat kebebasan

$\mathrm{df}=\mathrm{n}-\mathrm{k}-1$ atau $32-2-1=29$ maka diperoleh nilai untuk $\mathrm{F}$ tabel sebesar 3,328. Karena $\mathrm{F}$ hitung $(6,300)>\mathrm{F}$ tabel $(3,328)$, maka $\mathrm{H}_{\mathrm{o}}$ diterima, $\mathrm{H}_{1}$ ditolak, artinya bahwa budaya organisasi dan disiplin 
kerja secara bersama-sama (simultan) berpengaruh terhadap kinerja

\section{KESIMPULAN DAN SARAN}

\subsection{Kesimpulan}

1. Berdasarkan hasil pengujian hipotesis 1 (dimana variabel budaya organisasi) berpengaruh positif dan siginifikan terhadap kinerja PT. Rutan Palembang, ternyata hasil pengujian mendukung hipotesis sehingga hipotesis diterima. Dimana variabel budaya organisasi secara parsial berpengaruh signifikan terhadap kinerja.

2. Berdasarkan hasil pengujian hipotesis 2 (dimana variabel disiplin kerja berpengaruh positif dan siginifikan terhadap kinerja PT. Rutan Palembang ternyata hasil pengujian mendukung hipotesis sehingga hipotesis diterima. Dimana variabel disiplin kerja secara parsial berpengaruh signifikan terhadap kinerja.

3. Berdasarkan hasil hipotesis 3 (dimana variabel budaya organisasi dan disiplin kerja) berpengaruh positif dan signifikan terhadap PT. Rutan Palembang ternyata hasil pengujian mendukung hipotesis sehingga hipotesis diterima. Dimana variabel variabel budaya organisasi dan disiplin kerja secara simultan berpengaruh signifikan terhadap kinerja.

\subsection{Saran}

1. Agar karyawan tetap menunjukan budaya kerja yang baik terhadap perusahaan dengan loyalitas, tingkat partisipasi yang tinggi dan kesediaan untuk berusaha sebaik mungkin demi kepentingan perusahaan dalam meningkatkan prestasi kerja karyawan hendaknya perusanaan lebih memperhatikan dan memberikan kebebasan dan kepercayaan penuh serta tanggung jawab kepada karyawan dalam menjalankan tugasnya.

2. Untuk meningkatkan kedisiplinan yang baik agar karyawan bersedia untuk mengubah suatu perilaku serta sebagai suatu upaya untuk meningkatkan kesadaran dan kesediaannya mentaati semua peraturan perusahan maka pihak perusahaan/manajemen memberikan suatu motivasi terhadap karyawan untuk dapat merangsang lebih giat lagi bekerja.

3. Guna meningkatkan kinerja karyawan hendaknya perusahaan /manajemen lebih sering mengadakan pengawasan, guna meningkatkan kedisiplinan terhadap karyawan untuk bekerja lebih baik lagi guna menghasilkan pekerjaan yang memuaskan sesuai dengan target perusahaan.

\section{Daftar Pustaka}

A.A Anwar Parabu Mangkunegara, , Manajemen Sumber Daya Manusia Perusahaan, PT. Remaja Rosda Karya, Bandung. 2016

Bungin, Burhan H.M, Penelitian Kualitatif : Kencana Prenama Media Group, Jakarta, 2015

Edy Sutrisno, Manajemen Sumber Daya Manusia. Edisi Pertama, Cetakan Keempat, Kencana, Jakarta, 2015

Fuad Mas'ud, , Survai Diagnosis Organisasional (Konsep dan Aplikasi), UNDIP, Semarang, 2015

Faustino Cardoso Gomes, Manajemen Sumber Daya Manusia, Edisi ke 4, Penerbit Andi, Yogyakarta, 2015 
Hani Handoko, Manajemen Personalia \& Sumberdaya Manusia (Edisi 2), BPFE. Yogyakarta, 2017

Husein Umar, Riset Sumber Daya Manusia

Dalam Organisasi, Gramedia Pustaka, Jakarta, 2014

Malayu S.P Hasibuan, Manajemen Sumber Daya Manusia , Bumi Aksara, Jakarta, 2016

Marihot Tua Efendi Hariandja, Manajemen sumberdaya manusia: pengadaan, pengembangan, pengkompensasian dan peningkatan produktivitas pegawai, Grasindo, Jakarta, 2015

Sunarto, Perilaku Organisasi, Edisi Kedua, Amus, Yogyakarta, 2012
Sedarmayanti, Sumber Daya Manusia Dan Produktivitas Kerja, Mandar Maju, Bandung, 20115

Stephen P. Robbins, Prinsip-Prinsip Perilaku Organisasi, Diterjemahkan oleh Halida, Edisi Kelima, Erlangga, Jakarta, 2015

Sugiyono, Metode Penelitian Bisnis, Alfabeta, Bandung, 2015

Syafrizal Helmi Situmorang, 2008. Filasafat Ilmu dan Metode Riset, Usu Press, Medan.20015

Veithzal Rivai Manajemen Sumber Daya Manusia Untuk Perusahaan, Edisi Kedua, Raja Grafindo, Jakarta, 2015 